\title{
Towards an Optimized Emitter for Screen-Printed Solar Cells
}

\author{
A. Dastgheib-Shirazi ${ }^{1}$, G. Micard ${ }^{1}$, H. Wagner ${ }^{2}$, M. Steyer ${ }^{1}$, P.P. Altermatt ${ }^{2}$, G. Hahn ${ }^{1}$ \\ ${ }^{1}$ Department of Physics, University of Konstanz, 78457 Konstanz \\ ${ }^{2}$ Dept. Solar Energy, Inst. Solid-State Physics, Leibniz University of Hannover, 30167 Hannover, Germany
}

\begin{abstract}
The determination of suitable process parameters for $\mathrm{POCl}_{3}$ diffusion, with the aim of minimizing emitter recombination and obtaining satisfactory contactability of the homogeneous emitter, is the aim of this study. It can be shown that different emitters with low $R_{\text {sheet }}<60 \Omega$ /sq can result in significantly different emitter saturation current densities. Regarding the screen-printing metallization procedure, we observe that the resistance of a semiconductor-metal contact can vary on different emitters despite of the same sheet resistance.

In this study, the relevant process parameters for emitter optimization using $\mathrm{POCl}_{3}$-diffusion were determined with the help of a design of experiment (DoE). Thus, it is also possible to find optimized diffusion parameters without increasing the sheet resistance of the optimized emitter. To verify the efficiency potential of the emitter, a standard industrial solar cell process is applied, and the outcome is compared with results from simulations using Sentaurus Device. A significant increase in efficiency can be reached, with open circuit voltages $>640 \mathrm{mV}$ and average efficiencies well above $19 \%$.
\end{abstract}

Index Terms - homogeneous emitter, $\mathbf{P O C l}_{3}$-diffusion, metallization, simulation

\section{INTRODUCTION}

The influence of process parameters during $\mathrm{POCl}_{3}$ diffusion on the emitter formation is still the subject of current research [2-7]. The main goal is to fabricate optimized emitters that show low emitter recombination, as well as suitable contactability for screen-printing metallization. A still common but somehow misleading parameter for the evaluation of emitters is the emitter sheet resistance, which reflects only the density of electrically active phosphorus atoms. For a quantitative assessment of emitters in a screenprinting process, more attention should be paid to the profile of the electrically inactive phosphorus [3].

In the first part of this work we discuss the influences of the important diffusion parameters on emitter formation during the pre-deposition phase, using a design of experiment (DoE) approach. Based on previous work [1], we focus on the main parameters of the $\mathrm{POCl}_{3}-\mathrm{N}_{2} / \mathrm{O}_{2}$ gas flow ratio and diffusion temperature. The evaluation of the DoE allows us to find optimal diffusion parameters for emitter formation. Here, we focus on emitter structures that (in spite of constantly low sheet resistance) have decreased emitter saturation current densities $\mathrm{j}_{0 \mathrm{E}}$ and sufficient metal-semiconductor contactability.

In order to show the extent to which the optimized emitter with $\mathrm{R}_{\text {sheet }}<60 \Omega / \square$ meets the requirements of a screenprinting process, the optimized emitter has been transferred to an industry-standard screen-printing process.

\section{DESIGN OF EXPERIMENT}

A DoE approach is used to systematically show the effects of diffusion parameters on emitter formation during the predeposition phase. For this purpose, we used the Box-Behnken Design [1], which allows a significant reduction of the diffusion experiments. In this investigation, four process parameters (duration, temperature, $\mathrm{POCl}_{3}-\mathrm{N}_{2}$ gas flow and $\mathrm{O}_{2}$ gas flow) are systematically varied, but we focus on the parameters temperature and $\mathrm{POCl}_{3}-\mathrm{N}_{2}$ gas flow, which have the strongest influence on emitter formation. For emitter characterization, the following methods are used:

- $\quad$ 4-Point Probe to obtain $\mathrm{R}_{\text {sheet }}$

- Quasi-Steady-State Photoconductance (QSSPC) to obtain $\mathrm{j}_{\mathrm{oE}}$ and $\mathrm{V}_{\text {oc,implied }}$

- $\quad$ Electrochemical Capacitance Voltage (ECV) to obtain the active dopant profile

- $\quad$ Secondary Ion Mass Spectrometry (SIMS) to obtain the total phosphorus density

- $\quad$ Glow Discharge - Optical Emission Spectroscopy (GD-OES) to obtain the phosphorus density in the PSG layer

The samples used for this part of the study were (100) oriented boron doped FZ wafers $\left(\mathrm{R}_{\mathrm{B}}=2 \Omega \mathrm{cm} \& 200 \Omega \mathrm{cm}\right)$ with a thickness of $250 \mu \mathrm{m}$. After the cleaning procedure, diffusion processes are carried out in a state of the art $\mathrm{POCl}_{3}$ diffusion furnace from Centrotherm. Only the temperature and the $\mathrm{POCl}_{3}-\mathrm{N}_{2}$ gas flow are varied, while all other parameters are held constant. After the characterization of the phosphorus-silicate glass (PSG) and its removal, the emitter is analyzed using the characterization tools listed above. In order to measure $\mathrm{j}_{\mathrm{OE}}$ and the implied $\mathrm{V}_{\mathrm{oc}}$, the samples are symmetrically passivated by plasma enhanced chemical vapor deposition (PECVD) using a-SiN ${ }_{\mathrm{x}}: \mathrm{H}$. Afterwards, joE and $\mathrm{V}_{\text {oc,implied }}$ are measured using the quasi-steady-state photoconductance (QSSPC) tool. The determination of $\mathrm{j}_{\mathrm{OE}}$ is done using the Kane Swanson method at high injection level $\left(\Delta \mathrm{n}=1-3 \times 10^{16} \mathrm{~cm}^{-3}\right)[8]$. 


\section{RESULTS OF THE DESIGN OF EXPERIMENT}

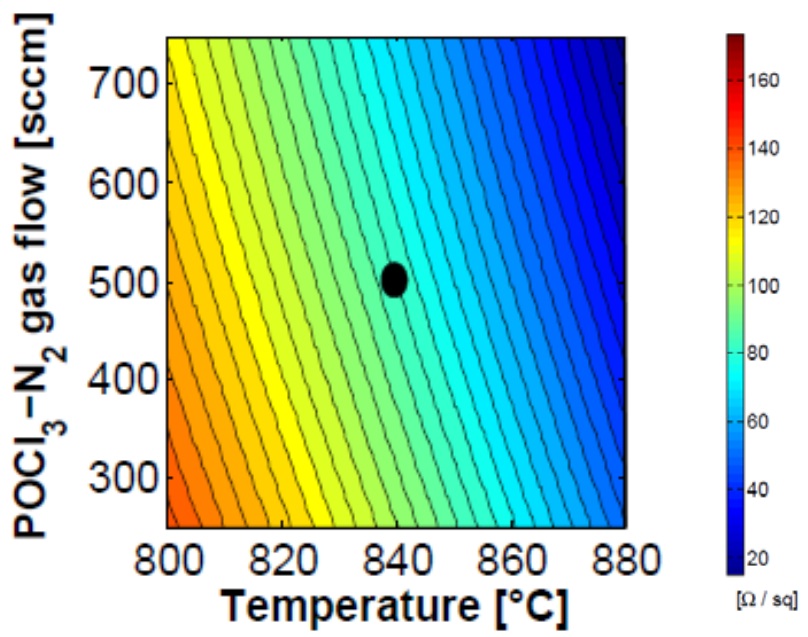

Fig. 1. Results of the DoE regarding $\mathrm{R}_{\text {sheet }}$ as a function of $\mathrm{POCl}_{3^{-}}$ $\mathrm{N}_{2}$ gas flow and process temperature.

Fig. 1 shows measured $\mathrm{R}_{\text {sheet }}$ as a function of $\mathrm{POCl}_{3}-\mathrm{N}_{2}$ gas flow and temperature range during pre-deposition. Here the sheet resistance increases significantly with higher $\mathrm{POCl}_{3}-\mathrm{N}_{2}$ gas flow and temperature.

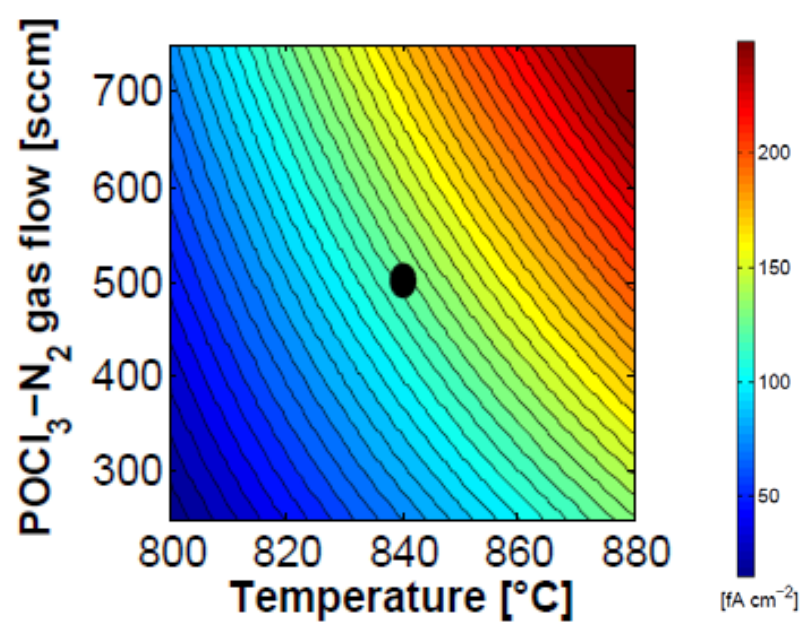

Fig. 2. Results of the DoE regarding $\mathrm{j}_{\mathrm{OE}}$ as a function of $\mathrm{POCl}_{3}-\mathrm{N}_{2}$ gas flow and process temperature.

Fig. 2 shows that an increase in temperature as well as $\mathrm{POCl}_{3}-\mathrm{N}_{2}$ gas flow leads to a significant increase in $\mathrm{j}_{0 \mathrm{E}}$. Through the combination of Fig. 1 and Fig. 2, parameter ranges of constant $R_{\text {sheet }}$ and strongly reduced $j_{0 E}$ can be determined.

By combining the DoE results with a Sentaurus Device simulation of a standard Si solar cell with Al-BSF, the potential of an optimized homogeneous emitter is visualized in
Fig. 3. The isosurfaces in Fig. 3 indicate the diffusion parameter range for constant solar cell efficiency. The reduction of the $\mathrm{POCl}_{3}-\mathrm{N}_{2}$ gas flow and the slight increase of the diffusion temperature lead to a maximum efficiency region whereby a gain of $0.6 \%$ abs can be achieved.

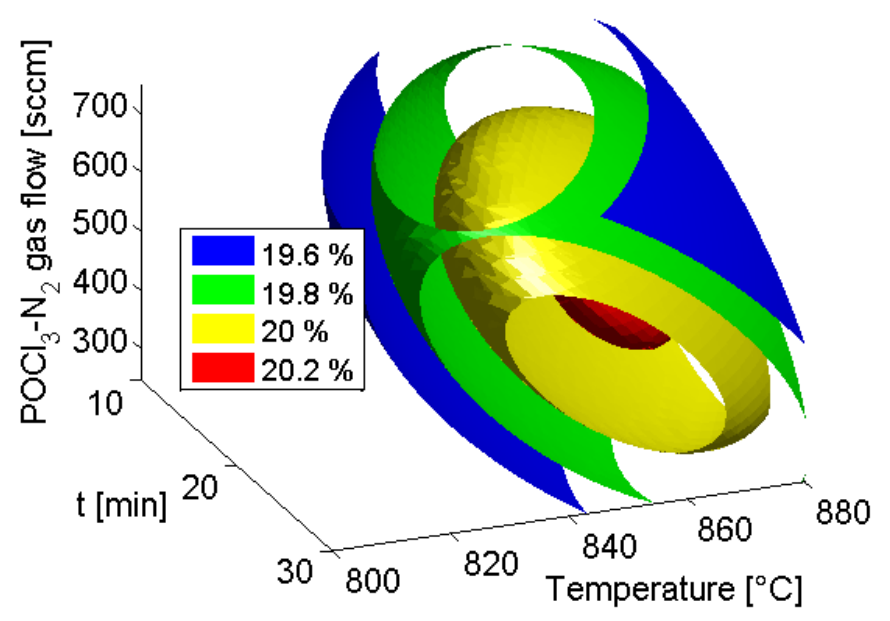

Fig. 3. 3-parameter isosurfaces of solar cell efficiencies as a function of $\mathrm{POCl}_{3}-\mathrm{N}_{2} / \mathrm{O}_{2}$ ratio, temperature and deposition? time, resulting from the combination of the DoE and solar cell simulation by using Sentaurus Device.

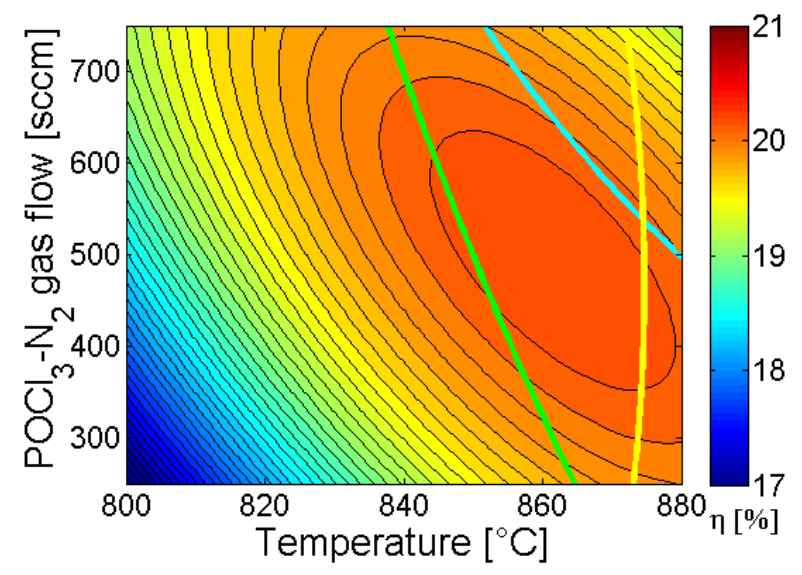

Fig. 4. 2D cross-section of Fig. 3 showing the simulated solar cell efficiencies as a function of $\mathrm{POCl}_{3}-\mathrm{N}_{2} / \mathrm{O}_{2}$ ratio and temperature during pre-deposition.

A 2D cross-section of Fig. 3 is shown in Fig. 4. An optimized parameter region with maximum solar cell efficiency can be achieved by adjustment of the $\mathrm{POCl}_{3}-\mathrm{N}_{2}$ gas flow and temperature. On the left side of the plot the green line indicates the efficiency limitation due to $R_{\text {sheet }}$ values higher than $60 \Omega / s q$. In this region the cell efficiency is limited by lower fill factors (FF). The maximum cell efficiency region is also limited by $\mathrm{j}_{0 \mathrm{E}}$ values above $210 \mathrm{fA} / \mathrm{cm}^{2}$ as illustrated by the blue line in Fig 4 . The $\mathrm{j}_{\mathrm{sc}}$ limit (yellow line) was calculated using the ECV profiles of the DoE. Here it must be taken into consideration that the 
contribution of emitter recombination that is caused by the electrically inactive phosphorous was not implemented in the device simulation. Taking into account the electrically inactive phosphorus would significantly reduce solar cell efficiency further in this region.

\section{P-PRECIPITATION}

Based on the results from the DoE, we see that the density of P-precipitates at the PSG/Si interface and in the emitter region is strongly affected by adjusting the diffusion parameters of $\mathrm{POCl}_{3}-\mathrm{N}_{2}$ gas flow and temperature.

To show the effect of precipitation at the PSG/Si interface, GD-OES measurements are carried out on PSG structures. Thereby it is possible to measure the course of concentration of $\mathrm{P}$ and $\mathrm{O}$ in the PSG layer and at the PSG/Si interface.

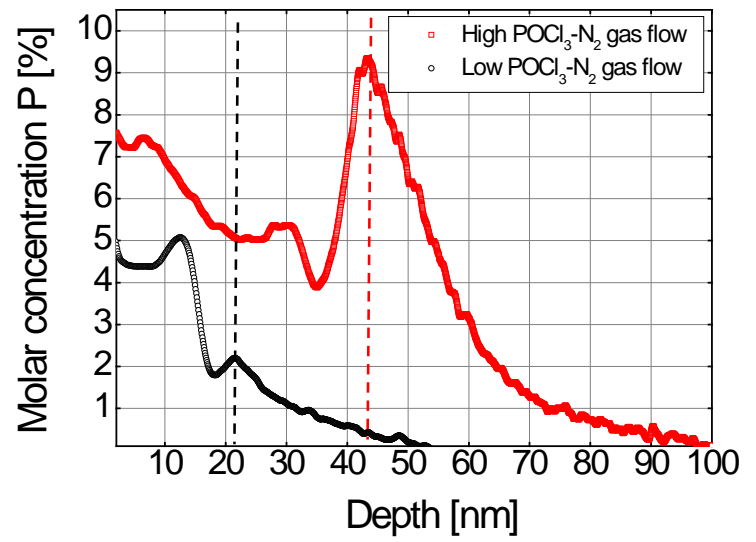

Fig. 5. Molar concentration profile of P in PSG and at the PSG/Si interface, measured by GD-OES. The interface is indicated by dashed lines for both samples.

Fig. 5 shows the concentration profile of $\mathrm{P}$ in the PSG layer as a function of the $\mathrm{POCl}_{3}-\mathrm{N}_{2}$ gas flow. A comparison of the concentration profiles makes it clear that the PSG has to be regarded as a multi-layered dopant source [9]. Furthermore, the reduction of the $\mathrm{POCl}_{3}-\mathrm{N}_{2}$ gas flow leads to several effects in the PSG and at the PSG/Si interface. On the one hand, the P concentration in the PSG layer is significantly lowered by the reduction of the $\mathrm{POCl}_{3}-\mathrm{N}_{2}$ gas flow. On the other hand, Fig. 5 indicates different concentration gradients in the sub-layers of the PSG as a function of the $\mathrm{POCl}_{3}-\mathrm{N}_{2}$ gas flow. The $\mathrm{P}$ concentration at the PSG/Si interface is drastically increased in the case of high $\mathrm{POCl}_{3}-\mathrm{N}_{2}$ gas flow condition. Therefore it can be assumed that on the one hand the high $\mathrm{POCl}_{3}-\mathrm{N}_{2}$ gas flow leads to an intensified formation of inactive phosphorous on the Si emitter surface region. On the other hand, this precipitate formation on the Si emitter surface region leads to an accumulation of the $\mathrm{P}$ in the PSG close to the PSG/Si interface. To examine the effect of the precipitate formation more closely, the concentration of $\mathrm{O}$ in the PSG, at the PSG/Si interface and in silicon is investigated.

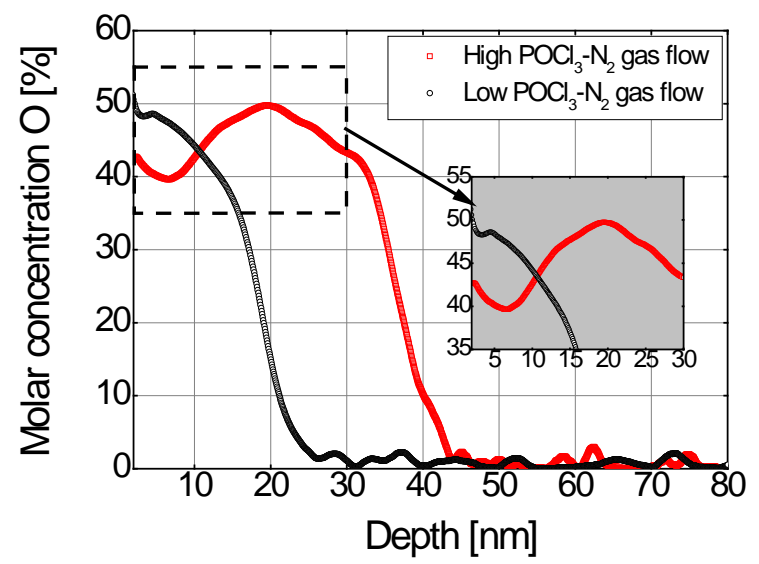

Fig. 6. Molar concentration profile of oxygen in the PSG and at the PSG/Si interface, measured by GD-OES.

In Fig. 6 the molar concentration profile of $O$ in the PSG and at the PSG/Si interface is shown. It is apparent that for the case of high $\mathrm{POCl}_{3}-\mathrm{N}_{2}$ gas flow, the $\mathrm{O}$ concentration drops in the first $5 \mathrm{~nm}$. The comparison with the high $\mathrm{P}$ concentration in Fig 5 within the first $5 \mathrm{~nm}$ supports the hypothesis of high amount of $\mathrm{P}_{\mathrm{x}} \mathrm{O}_{\mathrm{y}}$ in this region.

In the depth between $5 \mathrm{~nm}$ and $20 \mathrm{~nm}$ the $\mathrm{O}$ concentration increases in the PSG while the P concentration drops. This leads to a second PSG sublayer consisting of $\mathrm{P}_{\mathrm{x}} \mathrm{O}_{\mathrm{y}}$ and $\mathrm{SiO}_{2}$.

In the third sublayer the $\mathrm{O}$ concentration sharply decreases and the $\mathrm{P}$ concentration increases towards the PSG/Si interface. Fig. 5 and 6 indicate that the composition of the PSG layer and the thickness of the PSG sublayers are significantly correlated with the $\mathrm{POCl}_{3}-\mathrm{N}_{2}$ gas flow. As the $\mathrm{O}$ concentration within the first nanometers of the emitter does not seem to drop to zero, but shows molar concentrations of around $3 \%$, we could assume that the mechanisms of precipitate formation on the silicon surface may be influenced not only by $\mathrm{P}$, but also by the relatively high concentration of oxygen in silicon.

To ensure that the developed emitters are optimized to meet the requirements of a screen-printing process, the surface concentrations of the electrically active and inactive $\mathrm{P}$ in $\mathrm{Si}$ are measured by ECV and SIMS. Previous results show how strongly the $\mathrm{POCl}_{3}-\mathrm{N}_{2}$ gas flow affects the precipitation of $\mathrm{P}$, which leads to a significant increase in the surface concentration of the inactive $\mathrm{P}[2,3,10-15]$. 


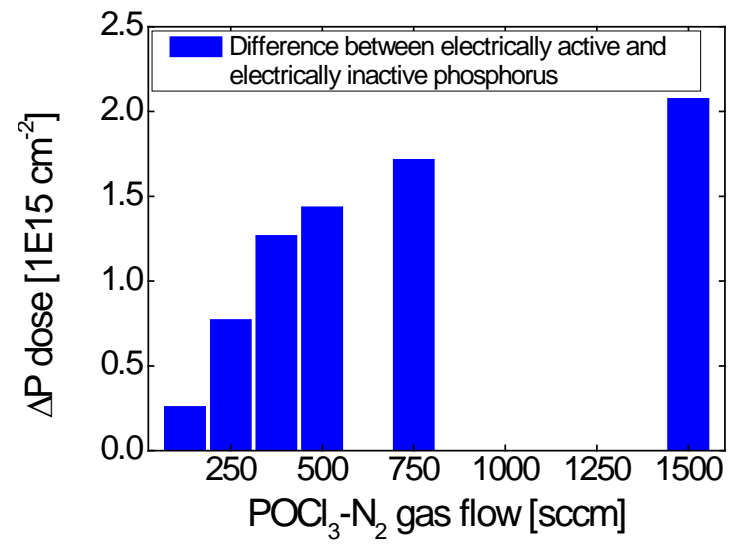

Fig. 7. Difference between the total and electrically active phosphorus surface concentration, $\Delta \mathrm{P}$, as a function of the $\mathrm{POCl}_{3}-\mathrm{N}_{2}$ gas flow during pre-deposition, as measured by ECV and SIMS.

By reducing the surface concentration of the inactive $\mathrm{P}$, we can significantly reduce emitter recombination without decreasing the emitter sheet resistance. However, the influence of the reduction of the P-precipitate density on the contact formation has to be investigated, in particular when using the screen-printing metallization procedure. For screenprinting metallization technology, low contact resistivity has to be assured for the metal-semiconductor contact. By the combination of high lateral conductivity and excellent ohmic contacts, a high FF, $\geq 80 \%$ can be achieved.

The influence of the electrically inactive $\mathrm{P}$ on the screenprinting based front-side contact can be illustrated by scanning electron microscopy (SEM) images. Therefore, emitters with different shares of inactive $\mathrm{P}$ are contacted via screen-printing. After this, the Ag front grid is wet chemically removed using $\mathrm{HF}$, and the contacts are analyzed by means of SEM.

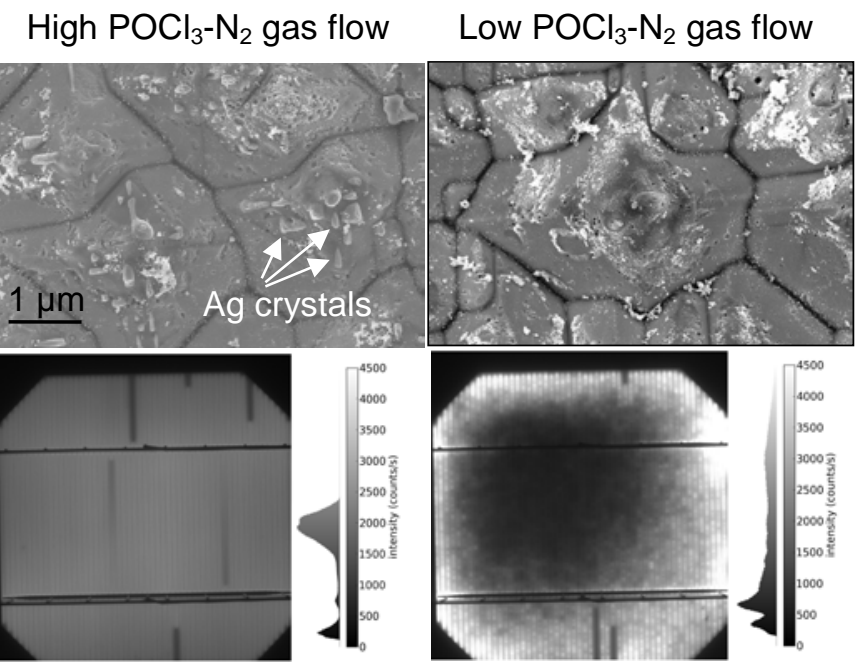

Fig. 8. Top: SEM analysis after removing the Ag finger by a wet chemical HF etching procedure. Bottom: EL images of the same samples.
Fig. 8 shows a comparison of two SEM images of emitters contacted by means of screen-printing. In the image on the left the emitter was processed with an increased $\mathrm{POCl}_{3}-\mathrm{N}_{2}$ gas flow. We see that the formation of Ag crystals is enhanced on the emitter with the higher $\mathrm{POCl}_{3}-\mathrm{N}_{2}$ gas flow. By contrast, in the image on the right, Ag crystals were scarcely formed for the emitter with reduced $\mathrm{POCl}_{3}-\mathrm{N}_{2}$ gas flow. It must thereby be noted that for both emitters the concentration of the active $\mathrm{P}$ is at the same level. This finding strengthens the assumption that not only the concentration of the electrically active $\mathrm{P}$, but also the density of the inactive $\mathrm{P}$ plays a decisive role in screen-printing metallization of the solar cell front-side. A juxtaposition of these SEM pictures with electroluminescence (EL) images of the same samples underlines this hypothesis. In the left EL image, which represents the emitter with the increased $\mathrm{POCl}_{3}-\mathrm{N}_{2}$ gas flow, the front-side contacting was successful. The measurement of the IV parameters of this sample shows a FF of $80.3 \%$ and a series resistance value of $0.29 \Omega \mathrm{cm}^{2}$. The evaluation of the IV characteristics of the right sample (reduced thickness of the electrically inactive $\mathrm{P}$ ) shows a FF of only $54 \%$ and a series resistance of $>2 \Omega \mathrm{cm}^{2}$ which can also be illustrated in the inhomogeneous and cloudy EL image.

To investigate the influence of the electrically active and inactive $\mathrm{P}$ on the contacting of the presented emitters, the transfer length method (TLM) was used. Results are given in Tab. I.

TABLE I

MEASUREMENTS OF THE CONTACT RESISTIVITY OF TWO EMITTERS IN A SCREEN-PRINTING PROCESS AS A FUNCTION OF POCL $_{3}-\mathrm{N}_{2}$ GAS FLOW DURING PRE-DEPOSITION

\begin{tabular}{|c|c|c|}
\hline & $\begin{array}{c}\text { High } \mathrm{POCl}_{3}-\mathrm{N}_{2} \\
\text { gas flow }\end{array}$ & $\begin{array}{c}\text { Low } \mathrm{POCl}_{3}-\mathrm{N}_{2} \\
\text { gas flow }\end{array}$ \\
\hline$\rho_{\mathrm{c}}\left[\mathrm{m} \Omega \mathrm{cm}^{2}\right]$ & $2.0 \pm 0.4$ & $117.4 \pm 23.4$ \\
\hline
\end{tabular}

\section{SOLAR CELl RESUltS}

To verify the potential of optimized homogeneous emitters from the DoE, screen-printed solar cells with full area AlBSFs and homogeneous emitters were fabricated on 6" boron doped Cz-Si material with a base resistivity of approximately $2.5 \Omega \mathrm{cm}$. The solar cells have a 3-busbar front grid (single print) and a thickness of approximately $160 \mu \mathrm{m}$. A standard PECVD $\operatorname{SiN}_{x}$ deposition (direct plasma, low frequency by centrotherm) is used for emitter passivation. The applied emitters have the same electrically active emitter surface doping of $\mathrm{N}_{\mathrm{s}} \sim 2 \times 10^{20} \mathrm{~cm}^{-3}$ However, they differ in the surface concentration of the electrically inactive P. For all emitters industrially feasible drive-in times are used.

TABLE II

COMPARISON OF AVERAGE IV PARAMETERS OF SOLAR CELLS WITH STANDARD AND OPTIMIZED HOMOGENEOUS EMITTERS 


\begin{tabular}{|c|c|c|c|c|}
\hline & $\mathrm{j}_{\mathrm{sc}}\left[\mathrm{mA} / \mathrm{cm}^{2}\right]$ & $\mathrm{V}_{\mathrm{oc}}[\mathrm{mV}]$ & $\mathrm{FF}[\%]$ & $\eta[\%]$ \\
\hline $\begin{array}{c}\text { Reference } \\
\text { Emitter }\end{array}$ & 36.9 & 633 & 79.7 & 18.6 \\
\hline $\begin{array}{c}\text { Optimized } \\
\text { Emitter }\end{array}$ & 37.6 & 643 & 80.1 & 19.4 \\
\hline
\end{tabular}

TABLE III

MEASUREMENTS OF THE CONTACT RESISTIVITY OF TWO EMITTERS IN A SCREEN-PRINTING PROCESS AS A FUNCTION OF \begin{tabular}{|c|c|c|}
\multicolumn{1}{c}{ POCL $_{3}-\mathrm{N}_{2}$ GAS FLOW } \\
\hline & $\begin{array}{c}\text { Reference } \\
\text { Emitter }\end{array}$ & $\begin{array}{c}\text { Optimized } \\
\text { Emitter }\end{array}$ \\
\hline$\rho_{\mathrm{c}}\left[\mathrm{m} \Omega \mathrm{cm}^{2}\right]$ & $0.9 \pm 0.2$ & $1.2 \pm 0.2$ \\
\hline
\end{tabular}

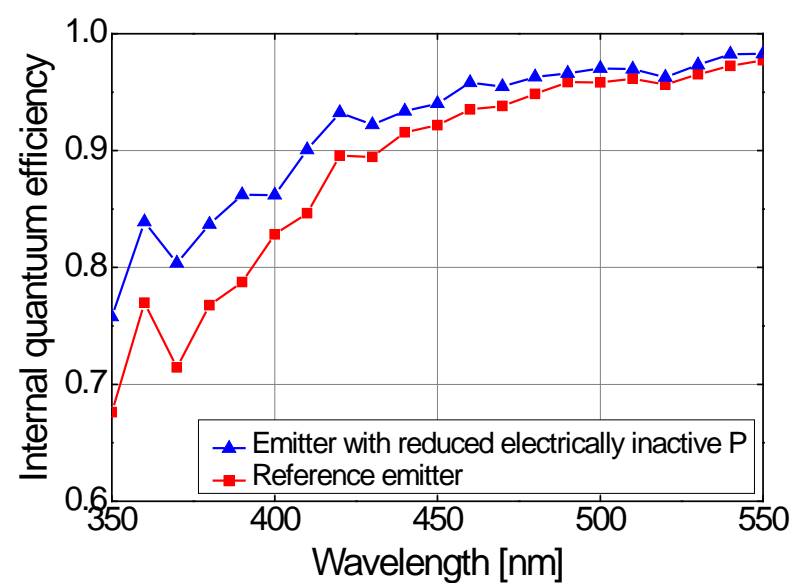

Fig. 9. Comparison between measured internal quantum efficiencies of solar cells with a reference emitter and an optimized emitter with reduced electrically inactive P.

By a slight adjustment of the diffusion parameters during the pre-deposition phase, an increase in $\mathrm{j}_{\mathrm{sc}}$ of $0.7 \mathrm{~mA} / \mathrm{cm}^{2}$, and an increase in $\mathrm{V}_{\text {oc }}$ of up to $10 \mathrm{mV}$ is obtained. Due to the constant level of the FF, a gain in efficiency of $0.6 \%$ abs is achieved. The increase in the internal quantum efficiency in the short wavelength region $(350-550 \mathrm{~nm})$ of the improved emitter structure shows that the reduction of the electrically inactive $\mathrm{P}$ not only reduces emitter recombination, but also increases the emitter's blue response. The analysis of the solar cells studied show that independently of the concentration of the electrically active $\mathrm{P}$, a lower limit of the concentration of the electrically inactive phosphorus must be present for satisfactory contacting. For the emitters examined here, this amounts to $\sim 6 \times 10^{20} \mathrm{~cm}^{-3}$. With the emitter structures studied, the lower limit of the plateau depth of the electrically inactive $\mathrm{P}$ is $\sim 60 \mathrm{~nm}$.

These experimental data confirm the simulated data of Fig. 4 and allow an estimation of the maximum achievable efficiency applying an optimized homogeneous emitter. A comparison of the solar cell results with Fig. 4 shows also that by further adjustment of the diffusion parameters even higher solar cell efficiencies may be achieved.
After determination of the optimal parameters in Fig. 4, the optimized emitter can also be transferred to novel multibusbar solar cell designs [16]. According to the initial results, efficiencies $>19.5 \%$ may be achieved.

\section{CONCLUSION AND OUTLOOK}

In this work, we used a design of experiment (DoE) study for the determination of the influence of diffusion parameters on emitter characteristics. We focused on optimizing the emitter saturation current density without significantly increasing the emitter sheet resistance. The combination of results from the DoE and the Sentaurus Device simulator shows good correlations between the diffusion parameters and the solar cell efficiency. Solar cell results of up to $19.5 \%$ have been achieved so far on standard p-type 6"' Cz material.

Further implementation of the electrically inactive $\mathrm{P}$ in the device simulation will reduce the gap between simulated and experimental solar cell results. This approach would allow a further gain in the efficiency of screen-printed solar cells via additional adjustment of the diffusion parameters and the front grid metallization structure.

\section{ACKNOWLEDGEMENT}

The financial support from the German BMU project FKZ 0325581 is gratefully acknowledged, in particular for the characterization equipment.

\section{REFERENCES}

[1] S.L.C. Ferreira, R.E. Bruns, H.S. Ferreira, G.D. Matos, J.M. David, G.C. Brandao, E.G.P. da Silva, L.A. Portugal, P.S. dos Reis, A.S. Souza, W.N.L. dos Santos, "Box-Behnken design: An alternative for the optimization of analytical methods," Analytica Chimica Acta, vol. 597, pp. 179-186, 2007.

[2] A. Dastgheib-Shirazi, M. Steyer, G. Micard, H. Wagner, P. Altermatt, G. Hahn, "Effects of process conditions for the $\mathrm{n}^{+}-$ emitter formation in crystalline silicon," in 38th IEEE PVSC, 2012, p. 1584.

[3] A. Dastgheib-Shirazi, M. Steyer, G. Micard, H. Wagner, P. Altermatt, G. Hahn, "Relationships between diffusion parameters and phosphorus precipitation during the $\mathrm{POCl}_{3}$ diffusion process," Energy Procedia, in press, 2013.

[4] H. Wagner, A. Dastgheib-Shirazi, R. Chen, S.T. Dunham, M. Kessler, P.P. Altermatt, "Improving the predictive power of modeling the emitter diffusion by fully including the phosphosilicate glass (PSG) layer," in 37th IEEE PVSC, 2011, p. 2957.

[5] G. Micard, A. Dastgheib-Shirazi, B. Raabe, G. Hahn, "Diffusivity analysis of $\mathrm{POCl}_{3}$ emitter SIMS profiles for semi empirical parameterization in Sentaurus Process," in 26th EU PVSEC, 2011, p. 1446.

[6] G. Micard, A. Dastgheib-Shirazi, M. Steyer, H. Wagner, P. Altermatt, G. Hahn, "Advances in the understanding of phosphorus silicate glass (PSG) formation for accurate process simulation of phosphorus diffusion," in 27th EU PVSEC, 2012, p. 1355. 
[7] M. Steyer, A. Dastgheib-Shirazi, H. Wagner, G. Micard, P. Altermatt, G. Hahn, "A study of various methods for the analysis of the phosphosilicate glass layer," in 27th EU PVSEC, 2012, p. 1325.

[8] D.E. Kane and R.M. Swanson, "Measurement of the emitter saturation current by a contactless photoconductivity decay method," in 18th IEEE PVSC, 1985, p. 578.

[9] R.N. Ghoshtagore , Phosphorus Diffusion Processes in SiO2 Films, Thin Solid Films, 25(2), 1975, p. 501-513

[10] D. Nobili, A. Armigliato, M. Finnetti, S. Solmi, "Precipitation as the phenomenon responsible for the electrically inactive phosphorus in silicon," Journal of Applied Physics, vol. 53(3), pp. 1484-1491, 1982.

[11] D.C. Douglass, T.M. Duncan, K.L. Walker, R. Csencsits, "A study of phosphorus in silicate glass with ${ }^{31} \mathrm{P}$ nuclear magnetic resonance spectroscopy," Journal of Applied Physics, vol. 58(1), pp. 197-203, 1985.

[12] E. Antoncik, "The influence of the solubility limit on diffusion of phosphorus and arsenic into silicon," Applied Physics A, vol. 58, pp. 117-123, 1994.

[13] A. Bentzen, J.S. Christensen, B.G. Svensson, A. Holt, "Understanding phosphorus emitter diffusion in silicon solar cell processing," in 21st EU PVSEC, 2006, p. 1388

[14] G. Beshkov, V. Krastev, H. Maciel, T.-A. Tang, V. Huang, "Xray photoelectron spectroscopy study of phosphorus silicate glasses," Surface and Coatings Technology, vol, 161, pp. 11-19, 2002.

[15] V. Vais, M. Milica, A.F. Brana, T. Leo, J.M. Fernandez, "Mechanisms involved in the formation of phosphosilicate glass from a phosphoric acid dopant source," Progress in Photovoltaics: Research and Applications, vol. 19(3), pp. 280285, 2010.

[16] S. Braun, R. Nissler, C. Ebert, D. Habermann, G. Hahn, "High efficiency multi-busbar solar cells and modules," in 39th IEEE, PVSC, 2013, in press. 